\title{
BAMBOO AS A STRUCTURE AND CONSTRUCTION MATERIAL IN THE DESIGN OF THE BAMBOO BUKIT VILLA
}

\author{
Azmi Afifah Nurazka ${ }^{1}$, Theresia Pynkyawati ${ }^{2}$, Muhammad Andre Mahardika \\ Umarella Davis ${ }^{3}$, Reva Regina Garnida ${ }^{4}$
}

1,2,3,4 Departement of Architecture, National Institute of Technology, Bandung, Indonesia

Corresponding author: nurazkafifah@gmail.com

Received: 21 April

2021
Revised: $2 \mathrm{Me}$

2021

\author{
Article History: \\ Accepted: $8 \mathrm{Me}$ \\ 2021
}

Available online: $14 \mathrm{Mei}$

2021

\begin{abstract}
Bamboo is a building material that is easily renewed, light weight and has the strength and flexibility with a resistance of 3 to 4 years, therefore bamboo can be an alternative material for building materials. Just as in the Villa Bukit Saung Bambu, is a building located in Caringin Tilu, Bandung Regency, to have a high humidity and bermaterial bamboo in the whole building, down to its structure and construction. Apart from being an aesthetic, even this material makes a special attraction for visitors, as well as the raised foundation to make a stilt-style building, the joint system between the horse- horse truss structure on the column, beams stacked in columns, column support on the foundation, floor construction that rests on the beams and roof coverings. The method used in this research is a qualitative descriptive method by means of direct observation in the field, observe the roof structure, columns, beams and foundations which are then compared with theories related to structure and construction, So it can be seen that bamboo can be an alternative building material, especially the structure of trusses horse- horse, beams, columns, floor and roof construction.
\end{abstract}

Keywords: Villa Design, Structure and Construction, Bamboo Material

\section{Introduction}

Bamboo is a material that is easily found with a very fast growth. This material is often used by the community for various types, including as crafts, furniture, and building materials. other than that bamboo can also be used as the structure of the building and construction because it has properties that easily updated, lightweight and strength also flexibility that can withstand the vibrations (Arsitag, 2020). In the use of bamboo in a building, Bamboo has a lifespan durability fit for use for up to 5 years (Handoko, EB 2015). If bamboo is preserved before it is applied to buildings, then the age of bamboo will increase again [9]. In the city of Bandung, precisely in the Cimenyan area there is a building that uses bamboo as its main material, namely Villa Bukit Saung Bambu (Tripcanvas, 2020). This villa is located in the highlands as well as the contour with a high soil moisture. Villa Bukit Saung Bamboo has 5 pieces of the building mass, ie 1 unit functions as a café and 4 other unit serves as a villa with a similar shape and size. The villa building has two floors of the building with a ground floor function as a family room and upstairs as a sleeping area. The entire structure and construction of the building uses bamboo, up to the connection system.

\subsection{Types of Bamboo as Building Materials}

From various types of bamboo, there are only a few that can be processed into building materials, including ater bamboo, bamboo betung, bamboo thorns, gombong bamboo and black 
bamboo. The bamboo species have an average height of 15-25 m (Sastrapradja, 1977). The following are several types of bamboo that can be used as building materials.

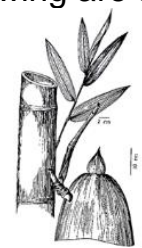

a. Bamboo Ater

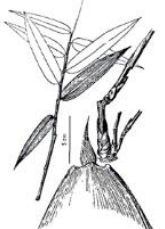

b. Black Bamboo

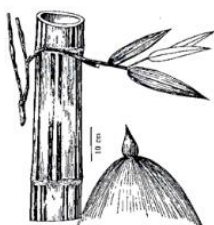

C. Bamboo Gombong

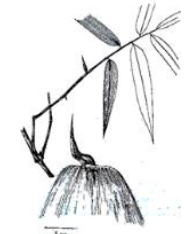

d. Bamboo Betung

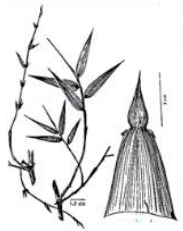

e. Bamboo Thorns

Figure 1. Sastrapradja, Types of Bamboo as Building Materials, 1977, Drawing. Source: Beberapa Jenis Bambu

\subsection{Borepile foundation}

Borepile foundations have several types, among others, the borepile foundation which is enlarged at the ends like a trapezoidal shape, Borepile foundations are straight, especially for rocky soils. borepile foundations with enlarged ends like a bell shape and borepile foundations in a straight form specifically for hard soil (Das, M. B., 1941).

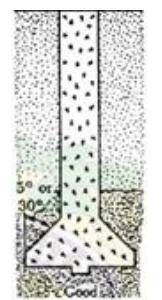

d. Trapezoid tip

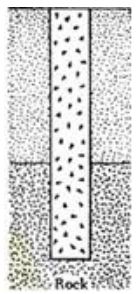

b. Especially for rocky land

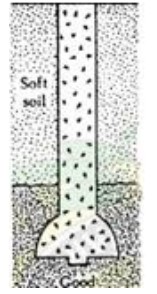

c. shaped Bel

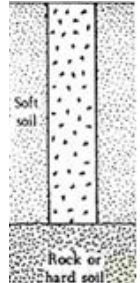

a.specificalhard ground

Figure 2. Das, M. B., Types of Borepile Foundations, 1941, Drawing

Source : Principles of Foundation Engineering Fourth Edition

\subsection{Bamboo Column}

Bamboo can be used as a column structure in buildings. however, bamboo has properties to flex against pressure. However, the deflection on bamboo can be overcome by installing a bolt in the middle of the bamboo columns that will strengthen the construction (Heinz Frick, 2004). The following is an explanation of the causes and solutions of deflection due to pressure on bamboo shown in the figure 3 .
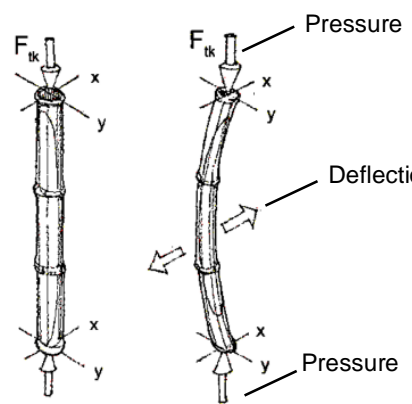

b. Pressure Deflection

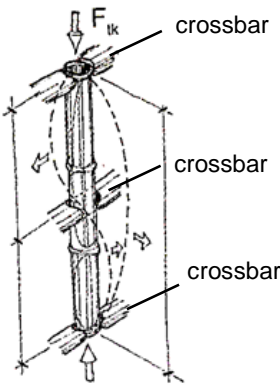

a. Deflection Prevention Solutions

Figure 3. Heinz Frick, Effects and Solutions of Deflection in Bamboo Columns, 2004, Drawing.

Source: Konstruksi Arsitektur 7 IImu Konstruksi Bangunan Bambu

\subsection{Bamboo Block}

Types of use of bamboo materials as building blocks (Heinz Frick, 2004):

a. A single beam or the transverse bamboo stalks on a building and the building has two pedestals.

b. Beams canal or bamboo stalks lengthwise on a building and having at least three support.

c. Bamboo floor beams to support the bamboo floor.

\subsection{Bamboo Flooring}

Types of use of bamboo materials as building floors (Heinz Frick, 2004) :

a. The floor of bamboo stems 
b. Bamboo slats floor

c. Bamboo woven floor

d. Floor from split bamboo

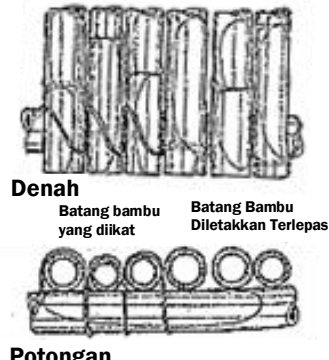
a. The floor of the Bamboo Rods

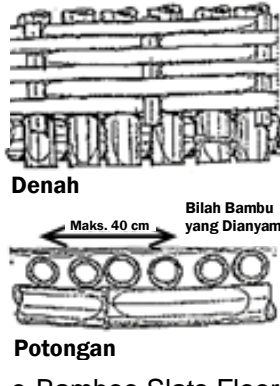

c. Bamboo Slats Floor

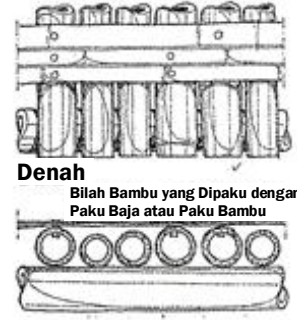

Potongan

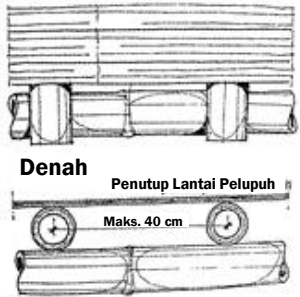

Potongan

b. Floor from split bamboo

Figure 4. Heinz Frick, Types of Bamboo Flooring, 2004, Drawing.

Source: Konstruksi Arsitektur 7 IImu Konstruksi Bangunan Bambu

\subsection{Processing of Bamboo Roof Structures and Construction}

Processing of bamboo roof structure and construction is the same as roof processing in general, using horse-horse bamboo, gording to rafters, the only difference is the use of the material (Purwito, 1995). For more details about the structure and roof construction bamboo can be seen in Figure 5 below.

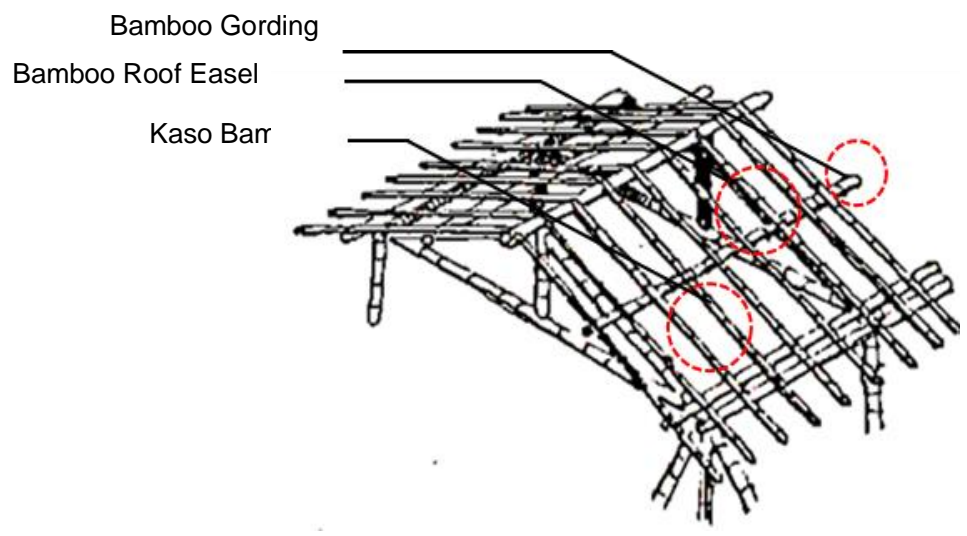

Figure 5. Purwito, Use of Bamboo Roof Structures and Construction, 1995, Drawing Source: The Application of Bambu for Earthquake-resistent Houses

\subsection{Bamboo Joint System}

The joints in bamboo building construction include roller bamboo joints and bamboo joint joints. Rolled bamboo joints are joints that allow horizontal movement of structural elements, like on window sills. Meanwhile, a bamboo joint is a connection that can withstand vertical and horizontal forces such as the rafters on the ridge beam (Heinz Frick, 2004). For more details about bamboo roller joints, see Figure 6 and bamboo joint joints in Figure 7 below.

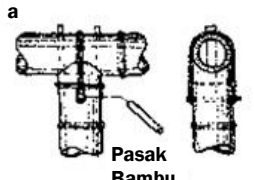

a.Connection with Double Tied Purus b

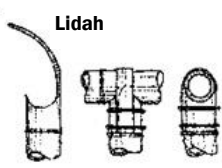

e.Connection with Tied Tongue

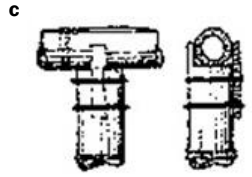

c. Pole with the clamp Purus and Tongue Tied

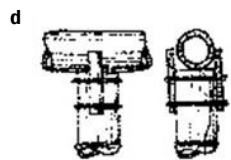

d. Connection with Tied Tongue Clamps

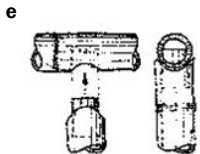

b. Connection with Purus Kayu

Figure 6. Heinz Frick, Various Connection Bamboo Roll, 2004, Drawing.

Source: Konstruksi Arsitektur 7 IImu Konstruksi Bangunan Bambu 


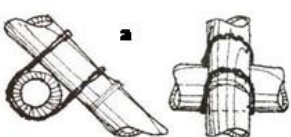

a. Connection with a fastener
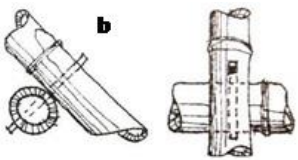

b. Connection with Bamboo Pegs
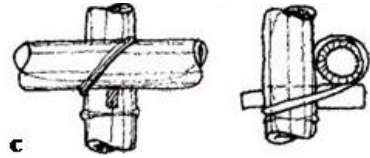

c. Floor and Column Fasteners with Wooden Pegs

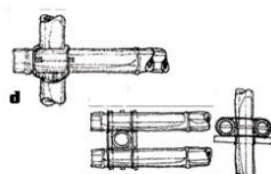

d. Multiple Floor Beams binder in columns with wood peg.

Figure 7. Heinz Frick, Types of Bamboo Joints, 2004, Drawing.

Source: Konstruksi Arsitektur 7 Ilmu Konstruksi Bangunan Bambu

\section{Methodology}

This research uses descriptive method is a method of collecting data on the use of bamboo materials on structures and building construction, the sizes of bamboo used, bamboo material processing methods and how to care and cleaning of bamboo in the Villa Bukit Saung Bambu. The first step is to explain the problem of using bamboo material as a structure and construction in buildings, the bamboo material connection system applied, ways of processing bamboo before being applied to the building and the way care is devoted to bamboo material. The second step is to collect data from the results of documenting the form of taking pictures and interviewing the owner of the Villa Bukit Saung Bambu building. The third step is to look for theoretical data relating to the use of bamboo materials for structure and construction. The results of the analysis can be used as the basis that bamboo can be used as a structural and construction material that can compete with other materials for buildings, especially residential buildings.

\section{Results and Discussion}

\subsection{Design of Villa Bukit Saung Bambu in terms of structural and construction systems}

\subsubsection{Bamboo Column Support on the Foundation}

In this building, there are two types of foundation used is the foundation and the foundation borepile batukali. All parts use a borepile foundation (DAS, M. B., 1941), it's just that bamboo is a material that is susceptible to water, so that the walls in the toilet area use brick walls. Then, in the bathroom using the foundation batukali (Kompas Properti, 2018) as a support for the wall.

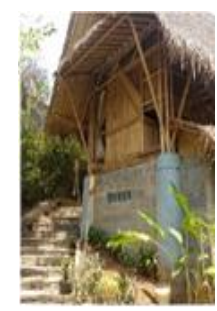

b.Batukali Foundation

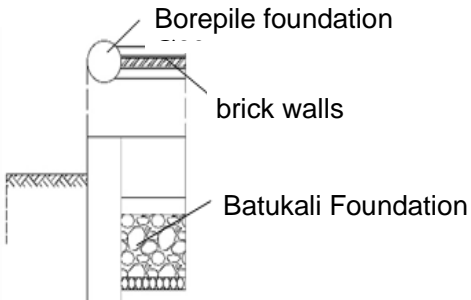

a. The foundation pieces Batukali

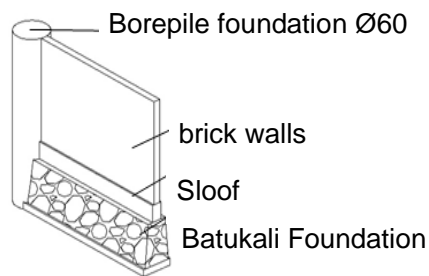

c. The foundation isometry

Figure 8. Foundations Details Batukali in Figure 9

Villa Bukit Saung Bambu has a total of 2 floors and a building area $34,5 \mathrm{~m}^{2}$ (Figure 9). The 1 st floor is a sitting room and a bedroom 2nd floor. This building has a split level which is illustrated in the module A-B figure 10, serves as a toilet with an area $6,9 \mathrm{~m}^{2}$

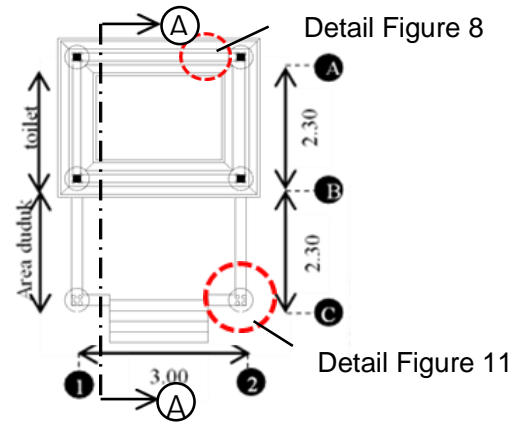

Figure 9. The Foundation Plan at Villa Bukit Saung Bambu

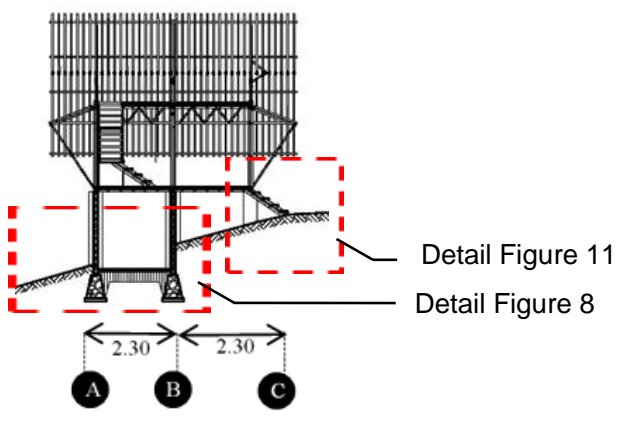

Figurer 10. Building Pieces A-A 


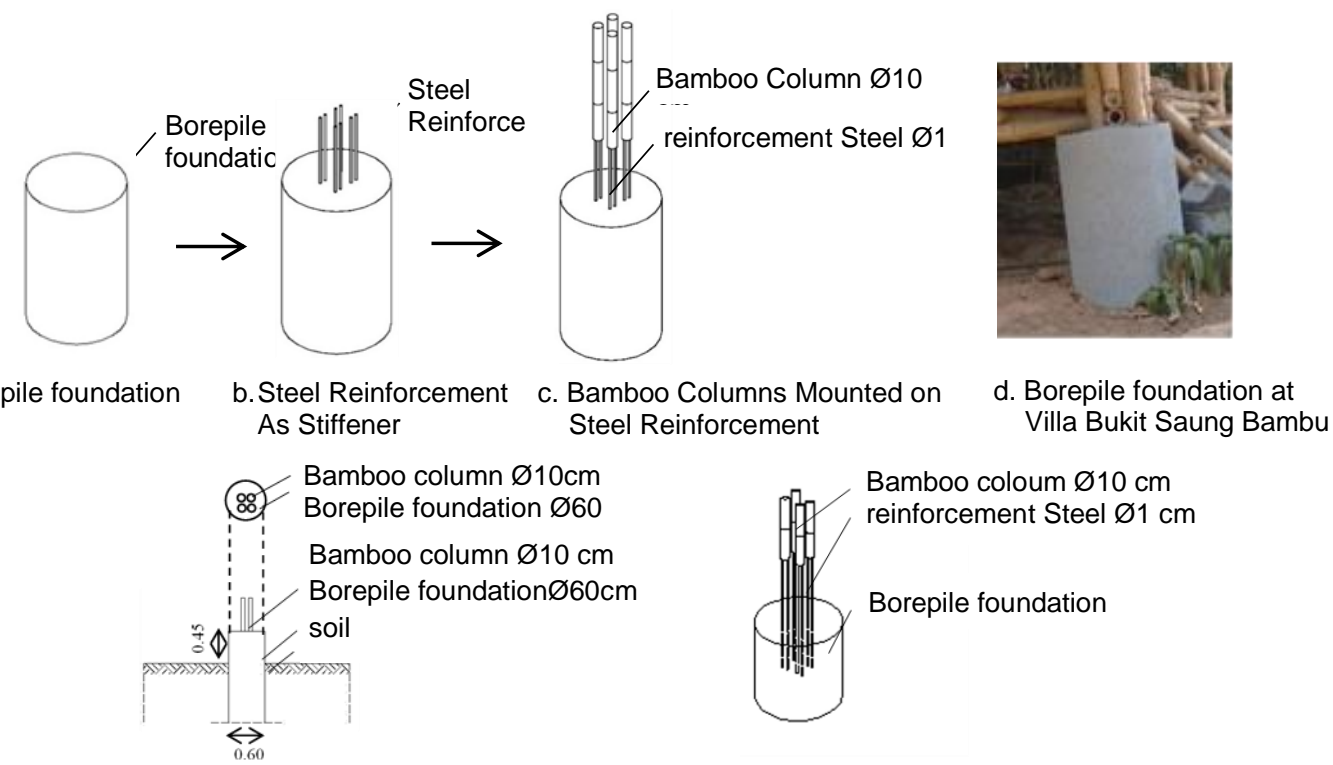

e. The foundation pieces Borepile

f. The foundation isometry Borepile

Figure 11. Details of Bamboo Column Installation on Borepile Foundation

The foundation on Villa Bukit Saung Bambu is elevated from the ground with a distance of $45 \mathrm{~cm}$ to avoid direct contact between the bamboo and the ground. For more details, it can be seen in Figure 12 below.

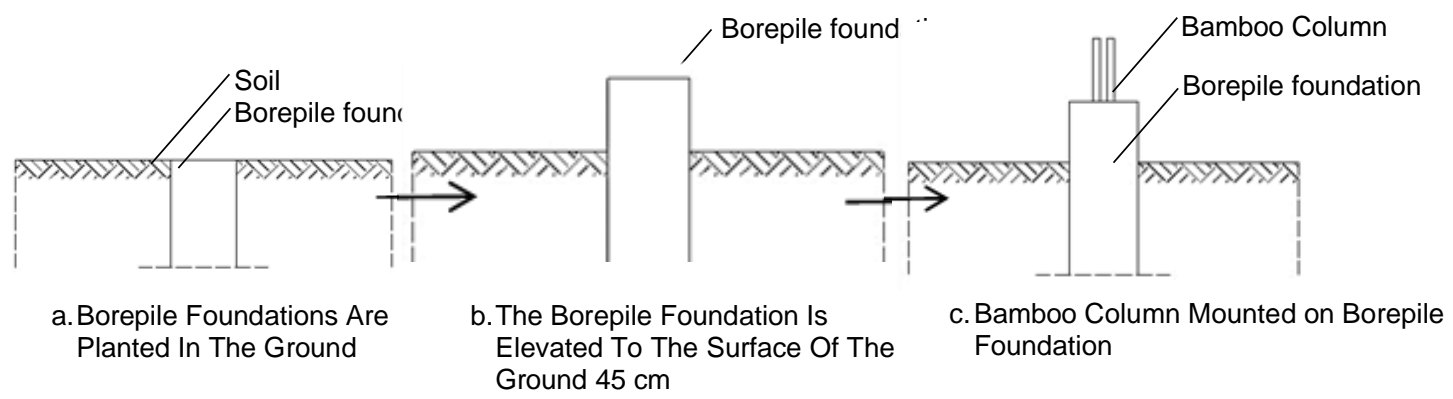

Figure 12. Foundation and Column Arrangement at Villa Bukit Saung Bambu

\subsubsection{Bamboo Column Support on the Foundation}

This building has a beam that spans 3 meters (Figure 13). Beams connected to the columns by means of nailed. The first step is to install 2 bolts at 2 points of the column to connect the column to the beam. After that the bamboo blocks are fixed to the bolts attached to the column. The next step is to install 2 other bamboo column points, so that the bamboo blocks are sandwiched between 2 bamboos. The final step to make it tighter, the bolts that have been installed are tightened by the nuts on each bolt (Heinz Frick, 2004). For more details, it can be seen in Figure 16 below.

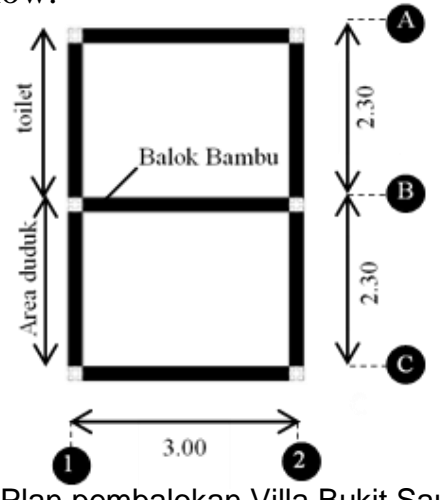

Figure 13. Plan pembalokan Villa Bukit Saung Bambu

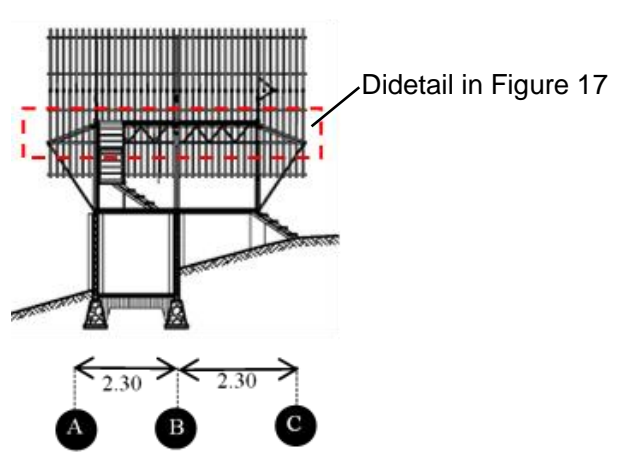

Figure 14. Pieces of Saung Bambu Villa Building 


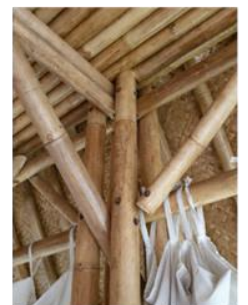

a.Bamboo Block

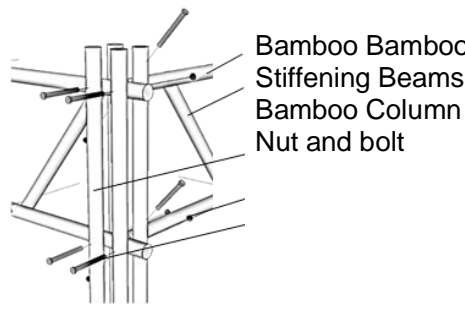

b. Beam Isometry

Figure 15. Block Connection System on Bamboo Columns

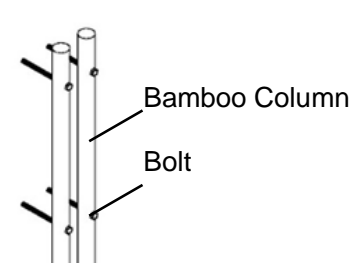

a. Bolts Installed in Column

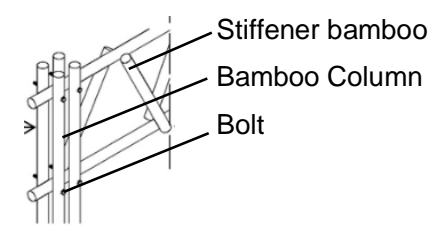

c. Installed with bamboo stiffeners

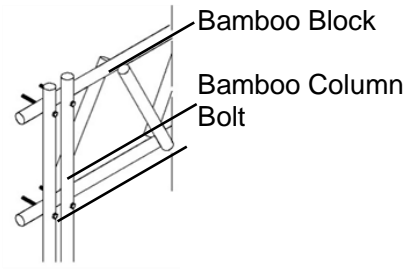

b. Bamboo beams Installed

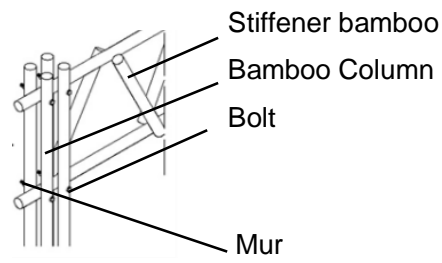

d. Couple tightened by Mur

Figure 16. Details of Installation of Beam Joints on Columns

How to install a beam with a span of 3 meters in this building by clamping a bamboo block between 4 bamboo columns which is secured by bamboo pegs shaped like nails. So that the blocks do not sag, then the bamboo blocks are stiffened by attaching $80 \mathrm{~cm}$ of bamboos to tie the bamboo blocks (Heinz Frick, 2004).

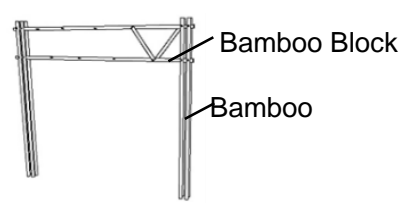

a. Two Fruit Bamboo beams nailed in Column Bamboo

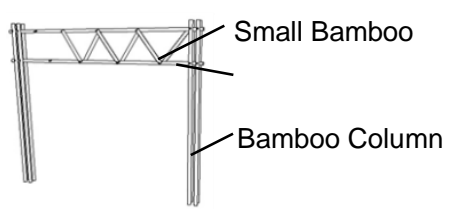

b. Balok Bambu Dikakukan Oleh Bambubambu Kecil Berukuran $80 \mathrm{~cm}$

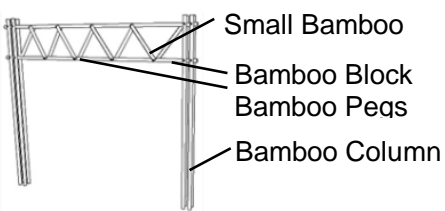

c. Bamboo beams stiffened By Small bamboo Measuring $80 \mathrm{~cm}$

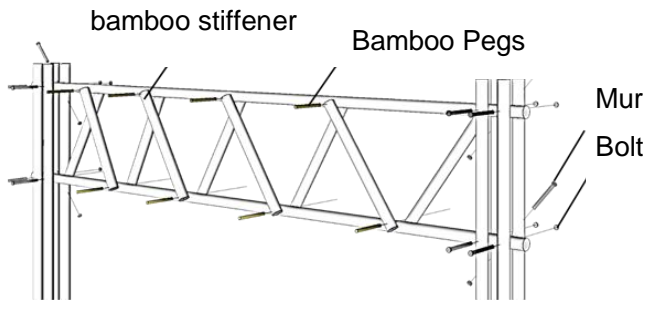

d. Beam Connection Details Villa Bukit Saung Bambu

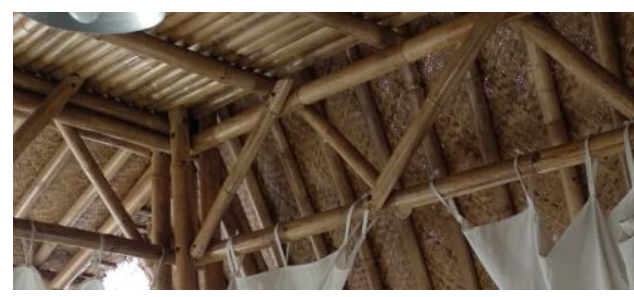

e. Bamboo blocks at Villa Bukit Saung Bambu

Figure 17. Use of Bamboo Block Construction 


\subsubsection{Easel Connection in Column}

How to connect easel in the column that is by using nuts and bolts nailed (Heinz Frick, 2004). The first step is to raise 2 points from 4 points in the column, in order to create a slope on the roof shape. Second step, clamp the easel between the 4 points of the column. After that, the truss and column are fastened using bolts and the last step the bolts that are fixed are tightened by the nuts (Purwito, 1995).

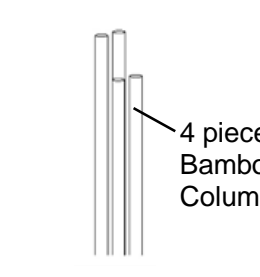

a.Bamboo Structure Column

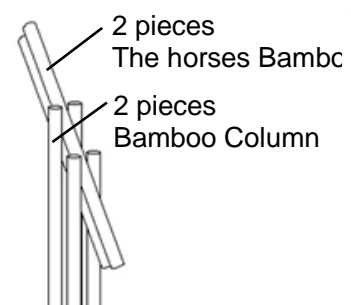

b. Addition of Two pieces easel Bamboo

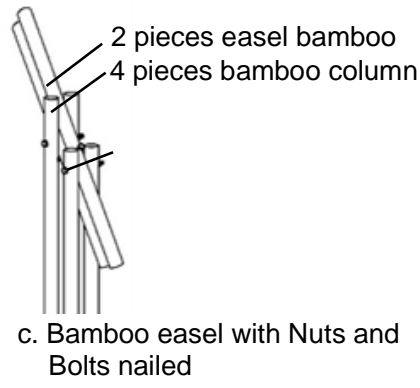

Bolts nailed

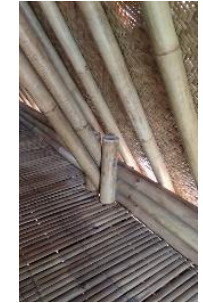

easel Bamboo

Villa Bukit Saung Bambu

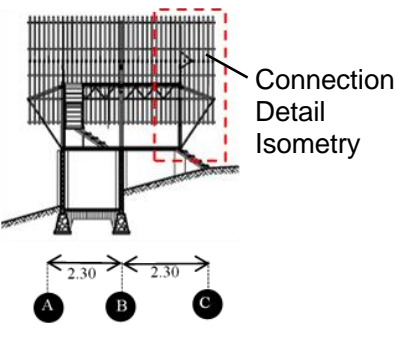

e. Building Pieces Villa Bukit Saung Bambu

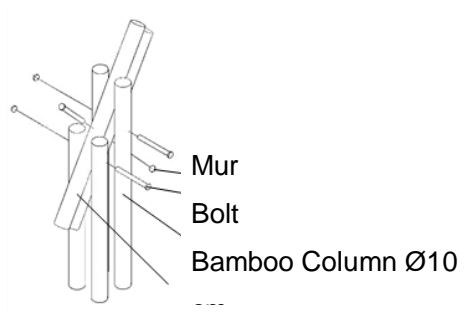

f. Connection Detail Isometry

Figure 18. The horses Connection Details on Column

The processing of the roof in this building uses three trusses where the middle truss does not use a broker in order to produce space under the roof cover. Roof covering deliberately widened to almost cover the ground floor in order to protect the ground floor which is open or not using wall. The roof of this building uses roof truss components made of bamboo, namely horses, gording dan kaso (Purwito, 1995). Not only the horses that serve as supporting the roof but there are also the pillars that serve to support the roof.

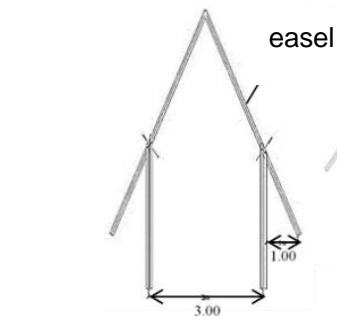

a. Looks easel

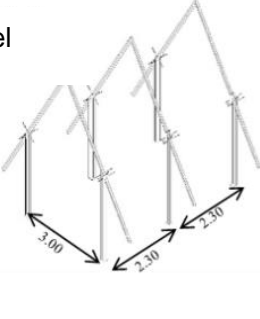

b. Easel isometry

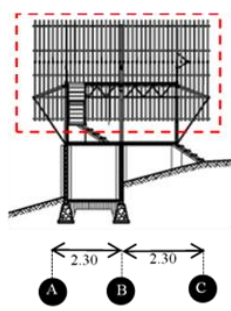

d. Pieces of Saung Bambu Villa Building

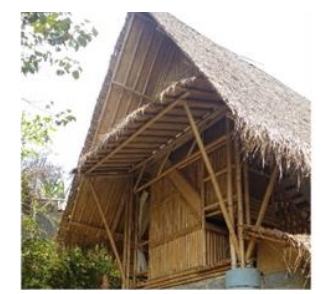

c. Roof Construction of Saung Bambu Villa

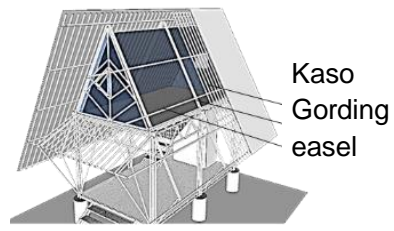

e. Isometry of Building Structures

Figure 19. Roof Structure System 


\subsubsection{Floor Construction System}

The bamboo flooring at Villa Bukit Saung Bambu consists of floors using bamboo, floor plates and foundation strips. The bamboo floor has a diameter of $10 \mathrm{~cm}$ with the bamboo intact. Then the bamboo floor rests on the floor plate with bamboo of the same size. While the floor plate itself rests on the foundation strip which is tied to the foundation or better known as the sloof. The bamboo floor and floor plate are connected by means of being stapled using bamboo, while the floor plate to strip foundations using nuts and bolts (Heinz Frick, 2004). For more details, it can be seen in Figure 20.

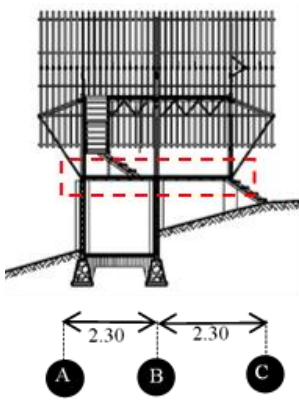

a. Building Pieces Villa Bukit Saung Bambu

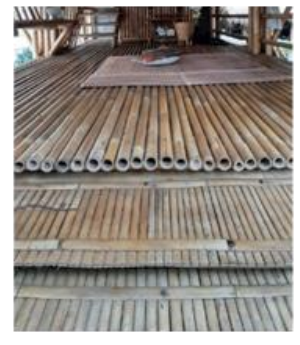

b. Floor Construction Villa Bukit Saung Bambu

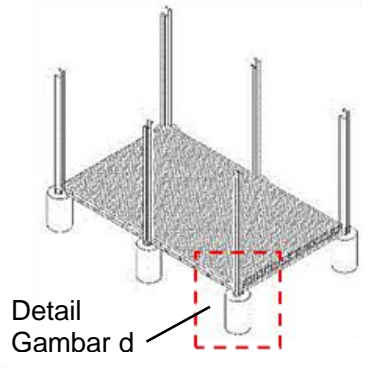

c. Construction Isometry

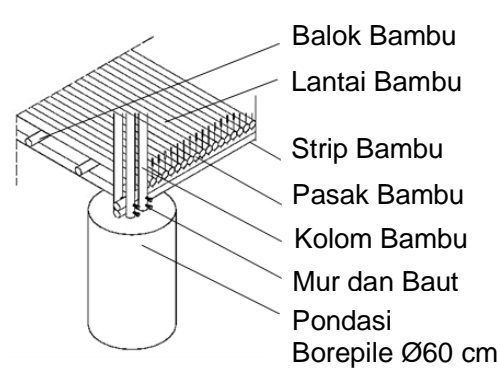

d. Floor Construction Connection Details on Columns and Foundations

Figure 20. Floor Construction System

How to install a bamboo floor construction on a column that rests on the foundation that is primarily how is nailed by nuts and bolts. The first step, clamping strip foundation in the column that has been installed on a foundation. Strip foundation is nailed to bolts and tighten the nut. The next step, installation of bamboo blocks on the foundation strip in a parallel manner with shorter spans. After that, install the bamboo floor on top of the bamboo blocks that have been installed. Then install the floor with bamboo using bamboo pegs in the form of nails (Heinz Frick, 2004). For more details, it can be seen in Figure 25 below.

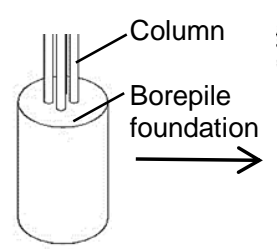

a. The foundation and bamboo columns have

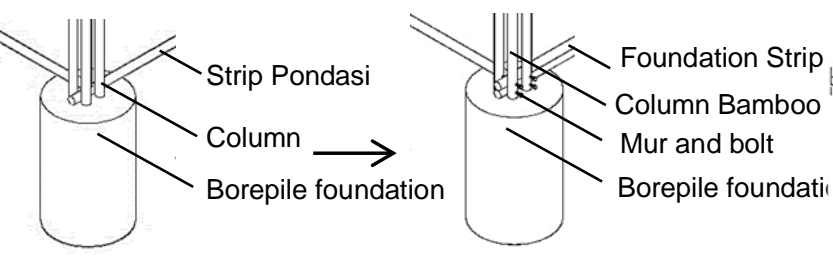

b. Installation of Foundation Strips

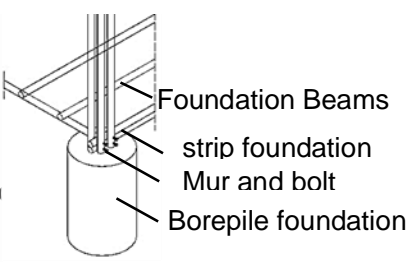

d. Installation of Bamboo Blocks on the Foundation

Figure 21. Construction Installation Method Floor

\subsection{System Structure and Construction of Villa Bukit Saung Bambu Viewed from Bamboo Material Usage}

\subsubsection{Bamboo Material processing on System Structure and Construction}

Before bamboo was used as a structural and construction material, bamboo went through the stage of preservation because bamboo contains high starch, bamboo is not resistant to termites. This preservation stage functions to make bamboo last for more than 5 years. Bamboo is cut at the age of 3-6 years because at that time bamboo has the highest quality and strength. And pay attention to the starch content on the stems which will affect the strength of bamboo against pests, termites and fungi. After cutting, the next stage of treatment is by soaking the bamboo which will be used as a structural system and construction of Villa Bukit Saung Bambu with sea water and then drying it. After drying, to make the bamboo more resistant to pests, termites and fungi, paint it with varnish. The first application process is to mix clear coat biovarnish with water with a ratio of 2 ingredients: 1 water. After that the two ingredients are stirred until evenly distributed then proceed with the grilling process. After that, the painted bamboo is dried overnight until it dries in a dry, dust-free and well-ventilated room (Media. Neliti, 2020). 


\subsubsection{How to Care and Clean Bamboo Material}

Daily maintenance at Villa Bukit Saung Bambu is only wiped and cleaned every week because it is one of the most effective and affordable ways. Treatment by wiping it also prevents the development of pests that will nest in the building. Apart from that, bamboo is also a structural system that decomposes easily, if the treatment is not right, especially if it is exposed to rain water. The Villa Bukit Saung Bambu building is included in the criteria because the roof of this building is made as wide as possible. In order to protect the rain water in direct contact with bamboo bamboo that will cause decay quickly (Muhsin, dkk. 2015).

\section{Conclusion}

Villa Bukit Saung Bambu is a commercial building that carries a traditional concept with the dominance of the use of bamboo material. The building is located in an area far enough from the city center to allow users to feel a rural feel. The building is designed to consist of four building masses, which aim to divide zoning between building functions. The four building masses consist of the receiving area, café, kitchen and huts. The entire mass of the building is designed by taking into account the activity flow of the building users. Most of the bamboo structures and constructions in the Villa Bukit Saung Bambu building use the peg system as a binder or connector for architectural, interior and ornament elements (Das, M. B., 1941). The advantages of this joint system are chosen because of its good durability and avoiding damage to the main structure material. By installing a good connection, bamboo can also be an aesthetic element in buildings. The use of bamboo structures in the Villa Bukit Saung Bambu building is not only because it carries a traditional concept but also because of the characteristics of bamboo which has strength, durability, and materials that are friendly to the environment with a relatively long period of use. The use of bamboo material as a whole can be seen in all building elements, from the structure, construction, to the supporting elements in the building, with good material care the bamboo structure in the building can last a longer period of time.

\section{References}

Arsitag. (2020). Bambu sebagai Bahan Bangunan. form: https://www.arsitag.com/article/bambusebagai-bahan-bangunan

Das, M. B., (1941). Principles of Foundation Engineering Fourth Edition, California, State University, Sacramento.

Frick, Heinz (2004). Konstruksi Arsitektur 7 IImu Konstruksi Bangunan Bambu, Pengantar Konstruksi Bambu.

Handoko, EB (2015). Peningkatan Durabilitas Bambu sebagai Komponen Konstruksi Melalui Desain Bangunan dan Preservasi Material

Kompas Properti. (2018). Bambu Bahan Bangunan Kokoh dan Antigempa. from: https://properti.kompas.com/read/2018/10/26/163418821/bambu-bahan-bangunan-kokohdan-antigempa?page $=$ all

Muhsin, A., Any, L.M.A.F., Hidayati, H.N., Purwanti, Y.A.D. 2015 Material Bambu sebagai Kostruksi pada Great Hall Eco Campus Outward Bound Indonesia. Jurnal Reka Karsa. from: Media.neliti. (2020). Material Bambu sebagai Konstruksi pada Bangunan. from: https://media.neliti.com/media/publications/220881-material-bambu-sebagai-konstruksipada-g.pdf.

Purwito, (1995). "The Application of Bambu for Earthquake-resistent Houses", In Ganapati, P.M., Janssen, J.A., Sastry, C.B., ed., Bambu People and Environment, Proceedings of the Vth International Bambu Workshop and the IV International Bambu Congress, Bali, 19-22 June 1995.

Sastrapradja, Setijati (1977). Beberapa Jenis Bambu.

Tripcanvas. (2020). Bukit Saung Bambu Cartil. form: https://indonesia.tripcanvas.co/id/bandung/ bukit-saung-bambu-cartil// 